\title{
Joanna Bednarek
}

\section{Praca biopolityczna}

i nowy skład klasowy

(Pragnienie-produkcja i żywa praca 2 -

\author{
Hardt i Negri $\left.{ }^{*}\right)$
}

Negri i Hardt stawiają w trylogii Imperium kontrowersyjną tezę o autonomizacji pracy biopolitycznej spod władzy kapitału. Twierdzą również, że tak „wyzwolona” praca stanowi podstawę politycznej emancypacji klasy robotniczej/ wielości. Zestawienie kategorii pracy biopolitycznej z wprowadzonym przez Deleuze'a i Guattariego pojęciem pragnienia-produkcji, jaki i porównanie tezy o jej autonomizacji z (również pochodzącym od autorów Kapitalizmu i schizofrenii) pojęciem stawania-się-mniejszościowym, uwidacznia zarówno ograniczenia, jak i potencjał teoretycznych propozycji autorów Rzecz-pospolitej.

Słowa kluczowe: biopolityka, produkcja, operaismo, praca niematerialna, Negri, Hardt

* Artykuł jest częścią większego projektu Pragnienie-produkcja i żywa praca i stanowi ciąg dalszy tekstu Życie jako moc deterytorializacji, który ukazał się w „Praktyce Teoretycznej” 2011, nr 2/3, http://www.praktykateoretyczna.pl/PT_nr23_2011_Biopolityka/12.bednarek.pdf 
„Trylogia Imperium” Michaela Hardta i Antonia Negriego, mimo zadłużenia wobec Gilles’a Deleuze’a i Feliksa Guattariego, jest dziełem pozostającym w dużej mierze w horyzoncie teoretycznym operaismo lub autonomii robotniczej, nurtu marksizmu, z którego wywodzi się Negri. Nurt ten, rozwijający się we Włoszech od lat pięćdziesiątych do dziś (mimo pewnego osłabienia intensywności w latach osiemdziesiątych, spowodowanego kryzysem ruchu lewicowego), proponuje wizję przemian dwudziestowiecznego kapitalizmu opartą zarówno na interpretacji Grundrisse Marksa ${ }^{1}$, jak i na zaangażowanych badaniach empirycznych ${ }^{2}$. O swoistości tej perspektywy stanowi rezygnacja z podziału na bazę i nadbudowę bez jednoczesnego przyjmowania, śladami Gramsciego, autonomii tego, co polityczne/społeczeństwa obywatelskiego.

Zamierzam zatem przedstawić koncepcję pracy niematerialnej/biopolitycznej Hardta i Negriego jako tyleż bliską teorii Deleuze’a i Guattariego, co zawierająca elementy odmienne i obce wobec koncepcji produkcji i polityki proponowanych przez autorów L'Anti-Oedipe.

Najistotniejszą innowacją operaismo jest zerwanie z funkcjonującą w ortodoksyjnym marksizmie tezą o neutralności sił wytwórczych. Jak podkreślają Mario Tronti i Raniero Panzieri ${ }^{3}$, organizacja produkcji jest kwestią polityczną (w słowniku Foucaultowskim można by powiedzieć: zespołem technik władzy): kapitał kształtuje siły wytwórcze poprzez organizację pracy. Siły wytwórcze są upolitycznione na najbardziej podstawowym poziomie, przy czym prymat przysługuje politycznej inwencji robotników, zarówno tej mikropolitycznej - stawiania oporu w miejscu pracy - i klasycznej, makropolitycznej - wysuwania politycznych roszczeń i postulatów poza nim. Klasa robotnicza jest, dzięki oporowi, jaki stawia, siłą napędową ewolucji kapitalizmú ${ }^{4}$. Sposoby walki pozostają zatem ściśle związane z formami produkcji.

1 Korzystam z przekładu angielskiego: K. Marx, Grundrisse, tłum. M. Nicolaus, London 1973, http://www.marxists.org/archive/marx/works/1857-gru/index. htm (dostęp 1.05.2010).

2 O tzw. ankietach robotniczych zob. R. Panzieri, Socialist Uses of Worker's Inquiry, http://www.generation-online.org/t/tpanzieri.htm (dostęp 1.05.2010) oraz Renesans Operaismo, [w:] Autonomia robotnicza, red. K. Król, Poznań 2007, s. 27-33.

3 R. Panzieri, Socialist Uses...; M. Tronti, Workers and Capital, http://www. geocities.com/cordobakaf/tronti_workers_capital.html (dostęp 1.05.2010).

4 Można by stwierdzić, że Tronti i Panzieri stawiają, wbrew Foucaultowi, tezę o prymacie oporu wobec władzy. Przełożenie tej tezy na język Foucaulta nie jest jednak do końca możliwe, jako że jej podstawą jest założenie o tożsamości politycznego oporu z ekonomiczną produktywnością klasy robotniczej. Zakłada się tu więc nieobecną u Foucaulta ontologiczną podstawę oporu niezależną od technik władzy - stanowi ją produktywność życia. 
Teoria składu klasowego, kładąca nacisk na powiązania między formami pracy i możliwościami walki, prowadzi do konieczności prowadzenia badań zaangażowanych (ankiety robotnicze). Opiera się ona na tezie, że proletariat nie jest bytem niezmiennym i monolitycznym: wraz z rozwojem sił wytwórczych zmieniają się formy pracy, zmienia się też struktura klasy robotniczej i jej możliwości stawiania oporu. W ramach składu klasowego można wyróżnić skład techniczny, obejmujący organizację procesu pracy: umiejętności robotników, maszyny oraz techniki dyscyplinowania, i skład polityczny, obejmujący techniki i praktyki oporu stosowane przez robotników. Skład techniczny i skład polityczny nieustannie na siebie wpływają: walka robotników wymusza zmiany w organizacji pracy, innowacje technologiczne i nowe techniki nadzoru, co owocuje przekształceniami składu klasowego, a w konsekwencji wynalezieniem nowych form oporu. Praca jest miejscem nieustannej walki politycznej ${ }^{5}$.

Teoretycy operaismo, zaangażowani od lat pięćdziesiątych dwudziestego wieku w analizy uwarunkowania przekształceń sposobu produkcji i składu klasowego, skupiają się głównie na dwóch, współczesnych im, fazach rozwoju kapitalizmu. Pierwsza z nich, fordyzm, powstała na fali dziewiętnastowiecznych komunistycznych walk robotniczych i odpowiedzi kapitału na nie. Pierwsza faza kapitalizmu industrialnego była epoką powstania i konsolidacji pierwszej figury składu klasowego - robotnika wykwalifikowanego, i jej politycznej mobilizacji, która przyjęła postać ruchu socjalistycznego i komunistycznego. Odpowiedzią kapitału i państwa były częściowe ustępstwa, dotyczące poprawy warunków pracy: wprowadzono ustawowe ograniczenie czasu pracy i systemy zabezpieczeń socjalnych. Jednocześnie polityczna walka robotników została poddana ograniczającym regulacjom: podporządkowano ją zasadom parlamentarnej reprezentacji (partie socjaldemokratyczne) i organizacjom z definicji broniącym wąsko zdefiniowanych, partykularnych interesów grup zawodowych (związki zawodowe). $\mathrm{Na}$ tym podwójnym ruchu opiera się Keynesowskie państwo dobrobytu/państwo opiekuńcze [welfare state], którego konstytucję opisują Hardt i Negri w pracy Labor of Dionysus ${ }^{6}$. Jednocześnie zmiany w sposobie produkcji (umasowienie, postęp mechanizacji, linia produkcyjna) dały początek nowej figurze: robotnika masowego, niewykwalifikowanego. Jeśli było to zwycięstwo, to dość dwu-

5 O czym przypomniało jakiś czas temu pismo „Recykling Idei”, tytułując jeden ze swoich numerów Pole pracy, pole walki („Recykling Idei” 2007, nr 9).

6 M. Hardt, A. Negri, Labor of Dionysus: a Critique of the State-Form, Minneapolis 2003 , s. 23-45. 
Neoliberalne reformy są nieraz przedstawiane jako realizacja postulatów roku 1968; „realizacja” ta była jednak ich ideologicznym zniekształceniem. Zakładała przede wszystkim oddzielenie tego, co kulturowe, od tego, co gospodarcze: walki nowych ruchów społecznych zostały w ten sposób skanalizowane

w stronę przestrzeni symbolicznych i medialnych reprezentacji

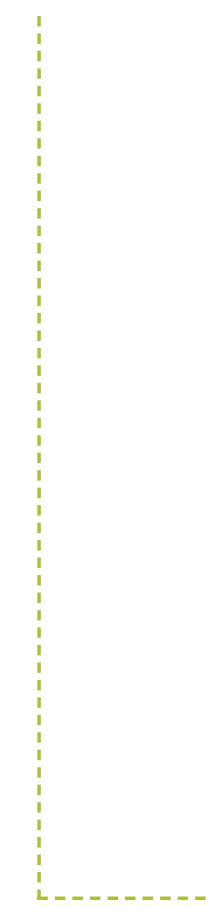

znaczne: klasa robotnicza, którą komunistyczna teoria i praktyka przedstawiała jako nośnik uniwersalnej emancypacji ludzkości, stała się korporacyjną grupą interesu.

Umowa między kapitałem, państwem i związkami oraz będąca jej efektem „mała stabilizacja” zostały jednak zakwestionowane za sprawą rozwijających się w latach sześćdziesiątych „nowych ruchów społecznych”. Tym, co je wyróżniało, było teoretyczne i praktyczne połączenie walk ekonomicznych, politycznych i kulturowych. Negri ujmuje istotę tych ruchów w formule „walka przeciwko pracy”" : walka przeciwko ustalonemu reżimowi pracy i czasu wolnego, przeznaczonego na konsumpcję; połączenie wytwarzania rzeczy i idei oraz wynajdywania nowych form wspólnoty; i wreszcie walka przeciwko podziałowi na sferę prywatną i publiczną („prywatne jest polityczne” to nie tylko hasło feministek, ale formuła dająca wgląd w istotę postulatów Nowej Lewicy w jej pierwotnym, radykalnym wydaniu).

Aktywność nowych ruchów społecznych i rewolta 1968 roku spotkały się z odpowiedzią kapitału, która przyjęła postać dwóch zintegrowanych strategii: z jednej strony ekonomicznej deregulacji i promowania modelu elastycznego zatrudnienia, z drugiej zaś - rynkowej ofensywy neoliberalnej wizji gospodarki i polityczności. Neoliberalne reformy są nieraz przedstawiane jako realizacja postulatów roku 1968; „realizacja” ta była jednak ich ideologicznym zniekształceniem. Zakładała przede wszystkim oddzielenie tego, co kulturowe, od tego, co gospodarcze: walki nowych ruchów społecznych zostały w ten sposób skanalizowane w stronę przestrzeni symbolicznych i medialnych reprezentacji. Stopniowa likwidacja zabezpieczeń socjalnych przedstawiana była jako przywrócenie obywatelom wolności wyboru; apologii indywidualizmu, elastyczności towarzyszyła patologizacja biedy (wynikającej rzekomo z wolnego wyboru). Brak bezpieczeństwa ekonomicznego równoważono naciskiem na bezpieczeństwo fizyczne i polityczne (rozwój coraz bardziej wyrafinowanych technik nadzoru, militaryzm).

Neoliberalna ofensywa to jednak tylko jeden, i to dość późny, funkcjonalny aspekt zmiany kapitalistycznego paradygmatu; z perspektywy operaismo najistotniejsze są modyfikacje, które nastąpiły nieco wcześniej i objęły zarówno skład techniczny, jak i skład polityczny pracy. Zwykle określa się je jako przejście od fordyzmu do postfordyzmu: fordowska

7 Tamże, s. 274-275, tychże, Multitude: War and Democracy in the Age of Empire, London 2004, s. 343.

8 Jak stwierdza we Fragmencie o maszynach Marks, jedną z tendencji rozwoju kapitalizmu jest wzrost znaczenia pracy złożonej; innowacje technologiczne zastępują 
dominacja (dotycząca zarówno liczebności, jak i waloryzacji) pracy przemysłowej, zorganizowanej jako masowa produkcja zestandaryzowanych towarów w wielkich fabrykach, została zastąpiona postfordowskim reżimem wymuszonej mobilności i elastyczności. Produkcja towarów odbywała się odtąd w krótkich, ,zindywidualizowanych” seriach, nierzadko zlecana podwykonawcom; nastąpił także wzrost roli i liczebności pracy w sektorze usług w stosunku do pracy w sektorze przemysłowym. Tym zmianom składu technicznego towarzyszyła dewaloryzacja tradycyjnej pracy w przemyśle, jak również narodziny nowego wzorca zatrudnienia: jednostka miała przemieszczać się między różnymi miejscami pracy i stanowiskami, nieustannie doskonalić i poszerzać swoje kwalifikacji zawodowe'. Fabryki zniknęły lub utraciły swoją uprzywilejowaną pozycję, co wiązało się z zanikiem tradycyjnej klasy robotniczej i zmianą w podmiotowości (składzie politycznym) klasy robotniczej: fordowskiego robotnika masowego zastąpił robotnik uspołeczniony ${ }^{10}$. Rozpoczęła się epoka realnej subsumcji.

stopniowo bezpośrednią pracę ludzką jako główny czynnik wartościotwórczy. Wymaga to zmiany definicji pracy: praca twórcza - projektowanie maszyn - poprzednio produktywna tylko pośrednio, staje się bezpośrednio produktywna. Innymi słowy, praca staje się uspołeczniona. Efektem jest zwiększenie ilości kapitału stałego względem kapitału zmiennego (siły roboczej), co na dłuższą metę musi uniemożliwić odtwarzanie stosunków kapitalistycznych (zob. K. Marks, Grundrisse, fr. 651-700, http://www.marxists.org/archive/marx/works/1857-gru/g13.htm, dostęp 1.05.2010).

9 M. Hardt, A. Negri, Imperium, tłum. A. Kołbaniuk, S. Ślusarski, Warszawa 2005, s. 40-50.

10 Zob. A. Negri, A. Negri, Marx Beyond Marx: Lessons on the Grundrisse, tłum. H. Cleaver, M. Ryan, M. Viano, New York-London 1991, s. xii, xxix, 197, 206-208. Temat przejścia do postfordyzmu został w latach osiemdziesiątych i dziewięćdziesiątych spopularyzowany (i nierzadko zwulgaryzowany) przez licznych teoretyków (J. Rifkin, Koniec pracy: schytek sity roboczej na świecie i początek ery postrynkowej, tłum. E. Kania, Wrocław 2001; R. Reich, Praca narodów: przygotowanie do kapitalizmu XXI wieku, tłum. L.A. Zyblikiewicz, Toruń 1996). Główna wada tych ujęć to brak perspektywy globalnej czy wręcz europocentryzm (gdzie Europa obejmuje także Stany Zjednoczone) - nie pojawia się w nich kwestia systemowych powiązań między przekształceniami składu technicznego pracy w krajach Północy a przenoszeniem ośrodków (zdewaloryzowanej) pracy przemysłowej do krajów Południa. Do pewnego stopnia krytyka ta odnosi się też do samych źródłowych idei powstałych w kręgu operaismo. Trzeba jednak pamiętać, że zostały one opracowane na podstawie badań empirycznych ściśle powiązanych z praktyką polityczną, o z definicji ograniczonej perspektywie. Badania te zdają sprawę z przekształceń produkcji w krajach Europy Zachodniej, głównie we Włoszech. Próbie nadania im uniwersalnego charakteru musi towarzyszyć poszerzenie perspektywy i zasięgu badań. Praca Negriego i Hardta, korzystająca z opracowań wielu badaczy zajmujących się przekształceniami produkcji w drugiej połowie dwudziestego wieku, częściowo spełnia te wymagania; amerykańscy 
Subsumcja formalna ma według Marksa miejsce, kiedy kapitał podporządkowuje sobie istniejące już, niezależne od niego procesy produkcji (podporządkowanie siły roboczej jest ograniczone do umowy o pracę); stosunki kapitalistyczne obejmują więc tylko część relacji społecznych. Natomiast w wypadku realnej subsumcji całe życie robotników podporządkowane zostaje potrzebom kapitału. Zdaniem Balibara sytuacja taka stanowi nieosiągalną granicę kapitalizmu:

Idealnym kresem [...] logiki [kapitału] byłoby coś, co Marks nazwał realnym podporządkowaniem siły roboczej kapitałowi, w przeciwieństwie do podporządkowania formalnego, ograniczonego do umowy o pracę: egzystencja robotników byłaby całkowicie określona przez potrzeby kapitału (zależnie od okoliczności, uzyskiwanie kwalifikacji zawodowych albo ich utrata, bezrobocie albo nadmierna praca dodatkowa, zaciskanie pasa albo przymusowa konsumpcja). Jednak granica ta jest historycznie nieosiągalna ${ }^{11}$.

Teoretycy operaismo, przeciwnie, uznają, że realna subsumcja jest historycznie osiągalna i osiągnięta została w postfordowskiej fazie kapitali$\mathrm{zmu}^{12}$. Fabryka nie jest już uprzywilejowaną przestrzenią produkcji: pojęcie fabryki spotecznej zdaje sprawę z faktu objęcia całego pola społecznego kapitalistycznymi stosunkami produkcji. Sprawia to również, że każda aktywność staje się bezpośrednio produktywna: znikają podziały na pracę i czas wolny, produkcję i konsumpcję, produkcję i reprodukcję siły roboczej, a także pracę produkcyjną i nieprodukcyjną.

Podporządkowanie całego pola społecznego kapitałowi nie jest jednak równoznaczne z niemożnością oporu; siła robocza jest w dalszym ciągu motorem kapitalistycznej produktywności: „Walka klas nie znika: zostaje przeniesiona we wszystkie momenty życia codziennego. [...] Realna subsumcja, daleka od eliminowania antagonizmu, nieskończenie go wzbogaca"13.

Konieczne jest więc zdanie sobie sprawy z przekształceń składu klasowego i usytuowania możliwych miejsc walki. Zmiany w kapitalistycznym sposobie produkcji (podporządkowanie produkcji wszystkich obszarów ludzkiej aktywności i powstanie „fabryki społecznej”) wymagają przede wszystkim nadania szerszego zasięgu pojęciu produkcji

apologeci postfordyzmu zbyt często ograniczają się do entuzjastycznego powitania nowej niematerialnej, elastycznej i ponadnarodowej gospodarki.

11 E. Balibar, Filozofia Marksa, tłum. A. Staroń, A. Ostolski, Z. M. Kowalewski, Warszawa 2007, s. 130.

12 M. Hardt, A. Negri, Labor of Dionysus..., s. 15.

13 A. Negri, Marx Beyond Marx..., s. xvi. 
i przeformułowania pojęcia pracy: rozszerzenia go na usługi czy nieodpłatną pracę opiekuńczą oraz rezygnacji z podziału na produkcję i reprodukcję siły roboczej.

Na podstawie tych założeń Negri i Hardt stawiają w trylogii Imperium tezę o hegemonii pracy niematerialnej. Odniesienie tego terminu jest tam złożone i różni się od definicji pracy niematerialnej proponowanych przez innych przedstawicieli marksizmu autonomistycznego ${ }^{14}$. Aby ukazać zarówno jego zalety, jak i słabości, należy więc przedstawić wszystkie jego wymiary, zarówno te, które łączą je z tradycyjnym, wypracowanym przez operaismo pojęciem pracy niematerialnej, jak i te, które są innowacją Negriego i Hardta.

Praca niematerialna nie oznacza tylko (czy głównie) tych rodzajów pracy, które Robert Reich nazywa analizą symboliczną: twórczej pracy $\mathrm{z}$ informacją, ideami, pojęciami ${ }^{15}$. Obejmuje ona przede wszystkim typy aktywności uznawane przez Marksa za wytwarzające wartość tylko pośrednio - w tym także pracę intelektualną, przetwarzanie informacji, innowacje; w paradygmacie pracy niematerialnej stają się one produktywne bezpośrednio ${ }^{16}$. Bezpośrednio produktywne stają się jednak także (może nawet przede wszystkim) inne działania zaliczane wcześniej do pracy nieproduktywnej i reprodukcji społecznej, którym tradycyjnie

14 Maurizio Lazzarato wprowadza np. pojęcie noopolityki, kładąc nacisk na rolę języka i komunikacji językowej we współczesnym składzie technicznym pracy oraz na wyzysk i kreatywność pracy intelektualnej jako głównych czynników decydujących o jej składzie politycznym; zob. tegoż, The Concepts of Life and the Living in the Societies of Control, [w:] Deleuze and the Social, red. M. Fuglsang, B. M. Sørensen, Edinburgh 2006, s. 171-190.

15 Zob. R. Reich, Praca narodów... Zarzut przypisywania zbyt wielkiego znaczenia hegemonii pracy intelektualnej czy związanej z technologiami informacyjnymi (stawiany $\mathrm{m}$. in. przez Petera Thompsona) jest trafny w odniesieniu do tekstów Negriego z lat 1990-1998, okresu, kiedy był związany z pismem "Futur Antérieur". Wersja 2.0 (według określenia Nicka Dyer-Witheforda) pracy niematerialnej, ta z okresu współpracy z Hardtem, jest już jednak wolna od tego jednowymiarowego nacisku na informację i pracę intelektualną. Zob. P. Thompson, Foundation and Empire: a Critique of Hardt and Negri, "Capital\&Class" 2005, No. 2; N. Dyer-Witheford, Cyber-Negri: General Intellect and Immaterial Labor, [w:] The Philosophy of Antonio Negri 1: Resistance in Practice, red. T.S. Murphy, A.-K. Mustapha, London-Ann Arbor 2005, s. 152.

16 Paradoksalnie, największą dwudziestowieczną obrończynią i kontynuatorką podziału na pracę nieprodukcyjną i produkcyjną (jednakże w ramach odmiennego niż Marksowski paradygmatu) była Hannah Arendt. Wprowadzona w Kondycji ludzkiej dychotomia work - labor nadaje pewną wartość pracy wytwórczej [poiesis], natomiast pracę pozbawioną wytworu redukuje do koniecznego, acz wstydliwego i z konieczności apolitycznego aspektu kondycji ludzkiej. 
odmawia się splendoru - praca usługowa oraz działania związane z wytwarzaniem, podtrzymywaniem i odtwarzaniem życia - tzw. praca reprodukcyjna ${ }^{17}$. Obejmuje to zarówno opłacaną pracę w sektorze usług, w tym pracę opiekuńczą, jak i nieopłacaną pracę domową, wykonywaną głównie przez kobiety ${ }^{18}$. Kolejnym aspektem pracy niematerialnej jest praca afektywna; polega ona na tworzeniu i podtrzymywaniu więzi międzyludzkich za pomocą emocji i komunikacji ${ }^{19}$.

W zakres pracy niematerialnej wchodzi także praca na roli, bardziej „niematerialna” niż praca przemysłowa:

Pod pewnymi względami klasy podporządkowane w okresie hegemonii [pracy] przemysłowej dostarczają klucza do zrozumienia zasadniczych cech hegemonii pracy niematerialnej. Rolnicy [...] zawsze czynili użytek z wiedzy, inteligencji i innowacji typowych dla pracy niematerialnej. $Z$ pewnością praca na roli jest niezwykle męcząca fizycznie - ziemia jest nisko, jak powie wam każdy, kto kiedyś pracował w polu - ale rolnictwo jest również nauką. Każdy rolnik jest chemikiem, dopasowującym typ gleby do właściwych zbóż, przekształcającym owoce i mleko w wino i ser, genetykiem, dobierającym najlepsze nasiona, aby udoskonalić odmiany roślin i meteorologiem, obserwującym niebo ${ }^{20}$.

17 Zob. Gender i ekonomia opieki, red. E. Charkiewicz, A. Zachorowska-Mazurkiewicz, Warszawa 2009.

18 Feminizacja nisko opłacanej pracy, zarówno przemysłowej, jak i usługowej, w gospodarce postfordowskiej to nie tylko kwestia statystyczna, ale strukturalne uwarunkowanie: ponieważ wejście na rynek pracy kobiet w krajach Północy odbyło się na neoliberalnych warunkach, bez jednoczesnej zmiany modelu rodziny $i$ ich niezależność ekonomiczna jest często uzależniona od pracy usługowo-opiekuńczej imigrantek (zob. R. Kurian, Globalizacja pracy domowej i ustug opiekuńczych, tłum. M. Michowicz, [w:] Gender...). Na kwestię produktywności nieopłacanej pracy kobiet jako jedne z pierwszych (w latach siedemdziesiątych) zwróciły uwagę działaczki z kręgu operaismo: Mariarosa dalla Costa i Alisa del Re.

19 Negri i Hardt wprowadzając w Imperium pojęcie pracy afektywnej, nie odwołują się w żaden sposób (na co zwraca uwagę Peter Thompson) do badań socjolożki Arlie Russell Hochschild, która jest autorką pojęcia pracy emocjonalnej i fundamentalnych badań nad rolą pracy afektywnej we współczesnej gospodarce (zob. A. R. Hochschild, Zarzadzanie emocjami: komercjalizacja ludzkich uczuć, tłum. J. Konieczny, Warszawa 2009; P. Thompson, Foundation and Empire..., s. 85). Trudno stwierdzić, czy brak tego przypisu jest kwestią ignorancji, czy złej woli... Trzeba także przyznać, że występujące w trylogii Imperium odwołania wskazują na niejaką fragmentaryczność wiedzy Negriego i Hardta na temat ekonomii feministycznej. W Imperium odwołują się wyłącznie do pracy Dorothy Smith, w Commonwealth do badań Chandry Mohanty, V. Spike Peterson i Valentine Moghadan.

20 M. Hardt, A. Negri, Multitude..., s. 109-110. 
Jak pokazują przykłady rolnictwa oraz afektywnej i reprodukcyjnej pracy kobiet, często jest to praca jak najbardziej fizyczna. Jej niematerialność polega raczej, jak podkreślają Negri i Hardt, na braku materialnego, odrębnego od samego działania wytworu ${ }^{21}$. Jej jedynym, nieodróżnialnym od samej pracy produktem jest życie, pojmowane jako zdolność rozwoju i nawiązywania relacji z otoczeniem. Dlatego też lepiej byłoby, jak stwierdzają już w Multitude Negri i Hardt, używać określenia praca biopolityczna:

Powinniśmy podkreślić, że praca zaangażowana w całą produkcję niematerialną pozostaje materialna - angażuje ona nasze ciała i umysły tak, jak każda praca. Tym, co niematerialne, jest jej produkt. Uznajemy, że „praca niematerialna” jest pod tym względem bardzo niejednoznacznym terminem. Być może byłoby lepiej rozumieć tę nową formę hegemoniczną jako „pracę biopolityczną22.

Tym, co wytwarza praca niematerialna, są relacje społeczne: uspołecznione, upolitycznione życie. Praca informacyjna, reprodukcyjna i praca afektywna to jej trzy uzupełniające się wzajemnie wymiary. Konstytutywnym składnikiem ich wszystkich jest współpraca. W biopolitycznej gospodarce postfordowskiej praca przestaje być indywidualna: kolektywność, uspołecznienie, komunikacja i współpraca stają się istotowymi cechami pracy jako takiej.

Hegemonia pracy niematerialnej nie polega, co podkreślają Negri i Hardt, na przewadze liczebnej pewnych typów pracy. Zarzut, że autorzy Imperium mylą się co do oczywistych faktów i danych albo mówią tylko o przekształceniach pracy w krajach Północy, nie jest trafny. Przede wszystkim mowa o tendencji rozwojowej, nie o statycznym obrazie faktów. Według Marksa opis tendencji rozwojowych systemu kapitalistycznego, choć zawsze związany z ryzykiem złej interpretacji symptomów ekonomiczno-społecznych, jest konieczną podbudową praktyki politycznej; Negri i Hardt idą jedynie w jego ślady ${ }^{23}$.

Jedną z oznak tej tendencji jest kapitalistyczna dewaloryzacja pracy przemysłowej (wytwarzania towarów - materialnych rzeczy); jest ona, ze względu na obecność tańszej siły roboczej, przenoszona do krajów Południa, gdzie przestaje być widoczna i chroniona (choćby i tylko nominalnymi) przepisami prawa pracy. Drugą stroną tego zjawiska jest

21 Następuje tu zatem zerwanie z paradygmatem godności poiesis i dewaluacji „trudu” jako pozbawionego materialnych efektów.

22 M. Hardt, A. Negri, Multitude..., s. 109.

23 M. Hardt, A. Negri, Multitude..., s. 140-153. 
nadmierna waloryzacja (określenie Saskii Sassen ${ }^{24}$ ) pracy symbolicznej - dziedziny PR, marketingu i reklamy. Materialny towar staje się, podobnie jak praca, prawie niewidoczny, nie będąc niczym więcej niż dodatkiem do marki.

Hegemonizując pole produkcji, praca niematerialna staje się paradygmatem pracy w ogóle - powoduje przekształcenia wszystkich typów pracy zgodnie ze swoim modelem. Oznacza to, że kooperacja, uspołecznienie, produktywność emocji stają się cechami każdej pracy, nawet pracy przemysłowej. Teza ta, kluczowa dla koncepcji hegemonii pracy niematerialnej, jest dyskusyjna ze względu na to, że ma postać twierdzenia niepopartego dowodami empirycznymi. Żeby ją zweryfikować, należałoby przeprowadzić szeroko zakrojone badania nad odmiennymi typami pracy (być może ze szczególnym naciskiem na pracę przemysłowa) w różnych częściach świata w celu sprawdzenia, czy faktycznie dokonały się takie przekształcenia; musiałyby one objąć organizację pracy, formy kontroli nad nią, jak również rolę samych pracowników w procesie pracy. W tym momencie można na pewno stwierdzić, że ogromny wpływ wywarła ekspansja sieci komunikacyjnych, która umożliwiła globalną redystrybucję pracy - gospodarka światowa jest dzięki niej systemem naczyń połączonych, w którym nieustanna komunikacja ma materialne następstwa.

Hegemonię pracy niematerialnej/produkcji biopolitycznej łączy też istotowy związek z realną subsumcją: paradygmat pracy niematerialnej, sprawiając, że aktywność biologiczno-społeczna ludzi jako taka stała się produktywna, przyczynił się również do tego, że zaczęła ona podlegać wyzyskowi o niespotykanym wcześniej zasięgu. Prowadzi ona bowiem do urynkowienia wszystkich aspektów życia ludzkiego i nie-ludzkiego (to drugie jest dzisiaj, dla tych, którzy chcą widzieć, z pewnością lepiej widoczne i bardziej oczywiste $)^{25}$.

Te warunki odpowiadają za powstanie nowego podmiotu pracy, który jest zarazem podmiotem politycznym: wielości [multitude]. Praca wielości jest - jako że polega na tworzeniu życia i stosunków społecznych - bezpośrednio polityczna. Pracujące podmioty wytwarzają to, co wspólne [the common]: immanentne pole relacji i powiązań, przeciwstawiające

24 S. Sassen, Globalizacja: eseje o nowej mobilności ludzi i pieniędzy, tłum. J. Tegnerowicz, Kraków 2007.

25 Aby zdać sprawę ze znaczenia tych przemian dla gospodarki i społeczeństwa, zaproponowane zostały pojęcia kapitału zwierzęcego i biokapitału (zob. K. Sunder Rajan, Biocapital: the Constitution of Postgenomic Life, Durham 2006; N. Shukin, Animal Capital: Rendering Life in Biopolitical Times, Minneapolis 2009; dziękuję Agnieszce Kowalczyk za zwrócenie mi uwagi na te prace). 
się transcendentnej organizacji tego, co uniwersalne, i umożliwiające wyłonienie się nowej organizacji politycznej.

[...] to, co wspólne wyznacza nową formę suwerenności, suwerenność demokratyczną (czy, dokładniej, formę organizacji społecznej, która przemieszcza suwerenność. [...] interes wspólny [...] nie jest przekształcany w coś abstrakcyjnego w ramach państwowej kontroli, ale raczej zostaje zawłaszczony przez osobliwości współpracujące w społecznej, biopolitycznej produkcji $[\ldots]^{26}$.

Podmiot uniwersalny wyłania się zawsze na skutek unifikacji: jednostkowe podmioty zostają zredefiniowane jako przypadki tego, co ogólne - obywatelstwa czy człowieczeństwa, i na tej podstawie upoważnione do politycznego uczestnictwa, za cenę odpolitycznienia pewnych sfer ich życia. Uniwersalny podmiot jest innym określeniem jedności ciała politycznego, z konieczności wyrzucającego poza swój obręb konstytutywne zewnętrze. Wielość jest natomiast złożona z osobliwości [singularities]: jednostek, których tożsamość nie jest konsekwencją funkcjonowania w ramach systemów kategorii ogólnych. Negri i Hardt definiują osobliwości również poprzez potrójną wielość: wielość zewnętrzną (powiązania z innymi osobliwościami), wielość wewnętrzną i wielość czasową (ciągłe przekształcenia na skutek interakcji z innymi ${ }^{27}$. Dlatego polityczna konstytucja wielości nie może polegać na stawaniu się ludem; jest to kategoria z definicji ujednolicająca i wykluczająca ${ }^{28}$.

Negri i Hardt nie twierdzą, że produkcja biopolityczna w postaci takiej, jaką znamy dzisiaj - podporządkowana mechanizmowi kapitalistycznej prywatyzacji i poddana dyktatowi wydajności - wyzwala sama z siebie. Stawiają tylko tezę, że hegemoniczna forma, jaką przybrała praca w gospodarce postfordowskiej, stwarza warunki dla ukonstytuowania się nowego uniwersalnego podmiotu politycznego, odpowiednika proletariatu z fazy przemysłowej kapitalizmu. Kluczowym z tych warunków jest autonomizacja pracy wielości wobec kapitału. W fazie przemysłowej kapitalizm odgrywał wobec pracy rolę częściowo pozytywną;

26 M. Hardt, A. Negri, Multitude..., s. 206.

27 M. Hardt, A. Negri, Commonwealth, Cambridge MA 2009, s. 339-340.

28 Przedstawione przez Agambena i Rancière'a analizy wewnętrznego pęknięcia kategorii ludu i aporetyczności, którą w konsekwencji jest ona nacechowana, wskazują na ten problem, nie są jednak w stanie rozwiązać go czy opracować dla niego alternatywy, ponieważ nie dysponują płaszczyzną ontologiczną umożliwiającą skonstruowanie podmiotu godzącego to, co wspólne, z różnorodnością (zob. G. Agamben, Czym jest lud?, tłum. P. Mościcki, [w:] Agamben: przewodnik Krytyki Politycznej, red. zespół, Warszawa 2010, s. 18-24; J. Rancière, Na brzegach politycznego, tłum. I. Bojadżijewa, J. Sowa, Kraków 2008, s. 71).

Negri i Hardt stawiają tezę, że hegemoniczna forma, jaką przybrała praca w gospodarce postfordowskiej, stwarza warunki dla

ukonstytuowania się nowego uniwersalnego podmiotu politycznego, odpowiednika proletariatu z fazy przemysłowej kapitalizmu 
dostarczając środków produkcji i organizując pracę, przyczyniał się do jej produktywności. W fazie realnej subsumcji jego działanie sprowadza się do wywłaszczania, wyzysku i nadzoru: ponieważ komunikacja, organizacja i relacje społeczne są integralną częścią produkcji biopolitycznej, kapitał staje się coraz bardziej zewnętrzny wobec pracy i przekształca się w pasożyta ${ }^{29}$ :

Kapitał - choć może ograniczać pracę biopolityczną, wywłaszczać jej wytwory, a nawet w pewnych wypadkach dostarczać niezbędnych narzędzi produkcji - nie organizuje produktywnej współpracy. [...] Intelektualne, komunikacyjne i afektywne środki współpracy są na ogół wytwarzane w samych produktywnych spotkaniach i nie mogą być kierowane z zewnątrz. W rzeczy samej, można stwierdzić, że kapitał zamiast umożliwiać współpracę, wywłaszcza ją, jako główny czynnik wyzysku biopolitycznej siły roboczej ${ }^{30}$.

Stwierdzenie to jest rzecz jasna kontrintuicyjne: wydaje się czymś oczywistym, że kapitalistyczna kontrola nad pracą to ważny czynnik wpływający na produktywność. Co więcej, sprawia ono też, zdaniem niektórych krytyków ${ }^{31}$, wrażenie sprzecznego z tezą o realnej subsumcji pracy pod kapitał. Skoro całe pole społeczne jest przeniknięte kapitalistycznymi stosunkami produkcji (prywatyzacja, wyzysk) i stosunkami władzy, skoro system kapitalistyczny doby Imperium nie ma zewnętrza, jak możliwa jest autonomia pracy? Zdaniem Nicholasa Thoburna i Finna Bowringa teza o autonomizacji pracy stanowi powrót Negriego do ortodoksyjnie marksistowskiej koncepcji neutralności sił wytwórczych. Produkcja zostaje tu ujęta jako obszar autonomiczny i odpolityczniony; prowadzi to do apoteozy pracy jako takiej i niekwestionowania ideałów nieskończonej produktywności i wydajności - kapitalistycznych kategorii niezakwestionowanych przez ortodoksyjny marksizm ${ }^{32}$. Negri odrzuca w ten sposób, zdaniem Thoburna, teoretyczne osiągnięcia operaismo: zdefiniowanie produkcji jako przestrzeni władzy oraz zaproponowaną przez Trontiego strategię walki z kapitalistycznym wyzyskiem poprzez odmowę pracy (a tym samym określonej przez kapitał tożsamości kla-

29 Zob. M. Hardt, A. Negri, Imperium, s. 379-381.

30 Tychże, Commonwealth, s. 140-141.

31 Zob. N. Thoburn, Autonomous Production?: On Negri's 'New Synthesis', "Theory, Culture and Society" 2001, Vol. 18, No. 5.

32 N. Thoburn, Deleuze, Marx and Politics, London-New York 2003, http:// libcom.org/library/deleuze-marx-politics-nicholas-thoburn-intro, s. 76 (dostęp 1.05.2010); F. Bowring, From the Mass Worker to the Multitude: a Theoretical Contextualization of Hardt and Negri's Empire, "Capital\&Class" 2004, Vol. 28, No. 2. 
sowej). Jak stwierdza Thoburn, paradoksalnie bliższy operaismo pozostaje Deleuze, podkreślający immanencję walk antykapitalistycznych wobec samej maszyny kapitalistycznej i sytuujący źródło oporu w wewnętrznych wobec społecznych urządzeń liniach ujścia. Podkreślając, że klasa definiowana jest w oparciu o pracę, która stanowi wyłącznie część kapitału, nie przypisuje żadnego subwersywnego potencjału tożsamości klasowej; jednocześnie podkreśla, że istotą walki proletariackiej jest stawanie-się-innym, stawanie-się-mniejszościowym ${ }^{33}$. Deleuze pozostaje więc, przy uwzględnieniu odmienności jego płaszczyzny teoretycznej, wierny tezie o realnej subsumcji i nie wprowadza esencjalistycznie pojmowanej pracy jako podstawy oporu; jest to stanowisko bardziej realistyczne i niepowtarzające błędów tradycyjnego marksizmu.

Teza o autonomizacji byłaby zatem nie tylko utopijna, ale też niebezpieczna: skoro wielość autonomizuje się za sprawą swojej pracy, może być tylko coraz lepiej, a upadek kapitalizmu jest niemal przesądzony. Oznacza to lekceważenie realności wyzysku, faktu, że produktywne życie jest w coraz większym stopniu poddawane wywłaszczeniu, między innymi dzięki ekspansji kategorii kapitału - pojawia się „kapitał ludzki” czy „biokapitał” (można tu przywołać narodziny kategorii biowłasności).

Zbytni optymizm Negriego może nieraz irytować ${ }^{34}$; jednak nie najmniejszą z przyczyn tej irytacji jest fakt, że prognozy końca neoliberalnej ofensywy i kryzysu kapitalizmu nie znajdują poparcia w opracowanej przez niego teorii ${ }^{35}$. Autonomizacja pracy i przekształcanie się

33 N. Thoburn, Deleuze, Marx..., s. 15-20, 123-130, 140-143.

34 Gdy np. jego rozmówca, Raf „Valvola” Scelsi, pyta: „czy nie sądzisz [...], że wśród dzisiejszych scenariuszy mogłoby być również powszechne anulowanie gwarancji społecznych, prowadzące do sytuacji opisywanych przez Dickensa? Do nowoczesności nacechowanej wielką, rozpowszechnioną biedą, z ogromnymi miastami zaludnionymi plebsem, pogrążonym w niewyobrażalnej nędzy....", Negri odpowiada niefrasobliwie: „Nie sadzę, aby taki scenariusz nędzy mógł się powtórzyć." (A. Negri, Goodbye Mr. Socialism, tłum. K. Żaboklicki, Warszawa 2008, s. 199-200).

35 „Neoliberalizm jako taki znalazł się [...] w stanie kryzysu, nie tylko z powodu tworzonej przez siebie gospodarczej nierównowagi, ale i dlatego, że Amerykanie jednostronnie nim kierują na płaszczyźnie politycznej; to kryzys tworzący warunki, z którymi kapitalizm już sobie nie radzi. [...] sądzę, że agresywny cykl neoliberalny definitywnie się skończył." (A. Negri, Goodbye Mr. Socialism, s. 203, 245). Trudno na gruncie teorii Negriego - odrzucającego wszak koncepcję cykliczności kapitalistycznej akumulacji - stwierdzić, dlaczego cykl neoliberalnej ekspansji miałby mieć się ku końcowi. Wydaje się, że tezę taką można postawić tylko w oparciu o jakąś wersję tej koncepcji. Dla przykładu, Beverly J. Silver, przewidując powszechny kryzys legitymizacji i nasilenie się protestów pracowniczych w bliskiej przyszłości, czyni to w oparciu o podejście badawcze 
kapitału w siłę wywłaszczania i kontroli może równie dobrze prowadzić do coraz agresywniejszej kolonizacji życia społecznego i biologicznego, wzrostu nierówności i częściowej rezygnacji ze swobód demokratycznych na rzecz funkcji policyjnych państwa i organizacji międzynarodowych; konflikt między pracą i kapitałem może przybierać postać coraz intensywniejszą.

Autonomia produkcji biopolitycznej nie polega na jej zewnętrzności wobec kapitalizmu; nie jest też czymś danym ani zdeterminowanym. Autonomizacja to pewna wewnętrzna tendencja rozwoju pracy, stwarzająca potencjał przemian politycznych; może ona jednak równie dobrze zostać stłumiona lub zastąpiona innymi (ponieważ Negri nie jest zwolennikiem pozytywistycznego ujęcia praw rozwoju ekonomiczno-społecznego jako koniecznych). Rozwój sił wytwórczych stwarza jedynie warunki zorganizowania pracy w sposób wolny od kapitalistycznego wyzysku. Dlatego Negri i Hardt obstają w Commonwealth przy obu tezach $^{36}$ : zarówno tezie o realnej subsumcji, jak i tezie o autonomizacji pracy. Druga z nich jest w rzeczywistości konsekwencją pierwszej. Ponieważ produkcja biopolityczna obejmuje wytwarzanie podmiotowości, relacji międzyludzkich i społecznych, obejmuje również przekształcanie stosunków pracy, które są jej częścią. Wielość jako podmiot polityczny musi jednak zostać ukonstytuowana (co Negri i Hardt podkreślają zwłaszcza w Commonwealth ${ }^{37}$ ) w postaci organizacji politycznej: „Klasa jest w rzeczywistości pojęciem biopolitycznym, które jest ekonomiczne i polityczne zarazem" 38 .

Zarzut, że trylogia Imperium każe nam postrzegać pracę jako już wyzwoloną i nie oferuje sposobów konceptualizowania wyzysku specyficznych dla realnej subsumcji, nie jest słuszny. Tezy o autonomizacji nie należy rozumieć intuicyjnie, przyjmując, że praca taka, jaką znamy, jest wyrazem autonomii produkcji biopolitycznej. Przydatne jest tu rozróżnienie Deleuze'a i Guattariego na makro- i mikropolitykę: poniżej jednolitego bytu (tutaj) znajdują się tworzące go sploty sił i intensywności. W wypadku każdej konkretnej pracy mamy do czynienia z wzajemnym mikropolitycznym uwikłaniem produktywnego potencjału pracy i jej wyzysku.

kładące nacisk na cykliczną i wahadłową dynamikę akumulacji kapitalistycznej i wystąpień pracowniczych (zob. B. J. Silver, Globalny proletariat: ruchy pracownicze i globalizacja po 1870 r., tłum. M. Starnawski, Warszawa 2009).

36 M. Hardt, A. Negri, Commonwealth, s. 141-149.

37 Tamże, s. 361-387.

38 Tychże, Multitude..., s. 105; zob. też: M. Ratajczak, Wielość - produkcja wspólnotowości, „Praktyka Teoretyczna” 2010, nr 1. 
W kategoriach ogólnych wyzysk polega przede wszystkim na zawłaszczaniu tego, co wspólne, prywatyzacji wspólnego dziedzictwa ludzkości: w wypadku tradycyjnej wiedzy ludów rdzennych znane od setek lat leki patentowane są przez naukowców, którzy je „odkryli”, przy jednoczesnym braku uwzględniania tytułu własności tych, którzy je wcześniej stosowali; wiedza tradycyjna jest tu, co stanowi przykład kontynuacji kolonializmu za pomocą innych środków, definiowana jako przednaukowa, „naturalna" ${ }^{39}$. Kolejny aspekt wyzysku to destabilizacja zatrudnienia. Pojecie przemysłowej armii rezerwowej traci dziś użyteczność, ale tylko dlatego, że każdy pracownik jest potencjalnie (lub aktualnie przez jakiś okres swojego życia) częścią tej armii, bo jego miejsce pracy nie jest pewne. Zmuszanie pracowników do ciągłej dyspozycyjności to zarazem sposób kontroli: uniemożliwia solidarność i podporządkowuje twórczą współpracę wymogom korporacyjnej „kreatywności”. Podobnie celem wydłużania i intensyfikacji czasu pracy jest zawłaszczenie i kontrola kreatywności. Ostatecznym skutkiem może jednak być tylko jej ograniczenie: jak stwierdzają Negri i Hardt, wielość produkuje wydajnie tylko wtedy, kiedy ma kontrolę nad własnym czasem ${ }^{40}$.

Przykładem wyzysku specyficznego dla systemu kapitalistycznego pozbawionego zewnętrza może być „kapitalizm kataklizmowy” opisany przez Naomi Klein w Doktrynie szoku ${ }^{41}$, polegający na wykorzystywaniu

39 M. Hardt, A. Negri, Multitude..., s. 184-185.

40 To odwołanie do niezdekonstruowanego kryterium produktywności jako podstawy krytyki kapitalizmu niepokoi; stanowi bowiem, w myśl krytyki Thoburna, przejęcie tego, co najgorsze z ortodoksyjnego marksizmu. Istnieje jednak inna droga interpretowania tego i podobnych argumentów; należy przede wszystkim zwrócić uwagę na rolę ideału produktywności w krajach komunistycznych. Zgodnie z ideologią leninowską produktywność i kult pracy były nie tyle celami samymi w sobie, ile koniecznym aspektem fazy przejściowej od kapitalizmu do komunizmu, sposobem na przyspieszoną modernizację. Negri nie definiuje jednak komunizmu jako punktu dojścia linearnego procesu modernizacyjnego, ale, za Marksem z Ideologii niemieckiej, jako ciągły i nieskończony ruch ku sprawiedliwości społecznej; dlatego nie powstaje u niego w ogóle problem przejścia od kapitalizmu do nowego porządku społecznego - komunizm jest nieustannym przejściem. Ze względu na rolę odmowy pracy w jego teorii nie można także uznać, że autonomiczna produktywność wielości ma być czymś podobnym do produktywności kapitalistycznej, jaką znamy. Być może zatem produktywność i wydajność należy rozumieć nie zgodnie z kryteriami ciągłego ilościowego wzrostu i jakościowej intensyfikacji, do jakich przyzwyczaił nas kapitalizm, ale jako wytwarzanie tego, co potrzebne wielości do życia (zob. K. Weeks, The Refusal of Work as Demand and Perspective, [w:] The Philosophy of Antonio Negri 1..., s. 125).

41 N. Klein, Doktryna szoku, tłum. H. Jankowska , T. Krzyżanowski, A. Makaruk, Warszawa 2008. 
wojen i katastrof naturalnych dla zawłaszczania tego, co publiczne lub tego, co wspólne. Zjawisko to ukazuje zarówno zewnętrzność kapitalizmu w stosunku do tego, co społeczne - „odbudowa” Iraku czy Nowego Orleanu służyły bowiem tylko wąsko pojmowanemu zyskowi określonych grup - i jednocześnie fakt, że działa on w ten sposób nie na obszary zewnętrzne (jak w wypadku kolonizacji ery imperializmu), ale na własne wnętrze; mamy więc do czynienia ze swego rodzaju wewnętrzną kolonizacją.

W świetle tezy o realnej subsumcji dość mocny zarzut wobec twierdzenia o autonomizacji stanowi jednak fakt, że, jak podkreślają Alex Callinicos, Peter Green oraz Aberto Toscano, Negri i Hardt nie biorą pod uwagę roli konkurencji i rozwoju rynków dla kapitału; ich teza o sile roboczej i jej oporze jako sile napędowej kapitalizmu nie jest fałszywa, ale z pewnością jednostronna ${ }^{42}$. Toscano wiąże to ograniczenie z założeniami ontologicznymi autorów Imperium: nauczyliśmy się od Foucaulta, że władza [potestas, pouvoir] jest produktywna, Negri i Hardt natomiast, sytuujący dynamikę i produktywność tylko po stronie mocy [potentia], przypisują jej rolę wyłącznie negatywną ${ }^{43}$. Wydaje się jednak, że nie świadczy to na ich niekorzyść; mamy w tym przypadku do czynienia z dwoma różnymi sposobami rozumienia produktywności. Rozróżnienie na moc i władzę pozwala odróżnić twórcze i konstytutywne oddziaływanie produkcji biopolitycznej od działania władzy, które jest z pewnością produktywne w rozumieniu Foucaultowskim: kontrola i prywatyzacja wytwarzają, za pomocą dyskursów i instytucji, które są ich środkami, podatne podmioty, a tym samym odtwarzają i modyfikują relacje władzy, asymilując lub niszcząc opór. Brak takiego rozróżnienia (ponieważ opór, ciało i przyjemność nie są odpowiednikami mocy) jest raczej ograniczeniem ontologii Foucaulta. Nieuwzględnianie przez metodologię operaismo, a tym samym przez Negriego i Hardta innych niż siła robocza czynników produktywności ujawnia jednak poważne (choć raczej metodologiczne niż ontologiczne) ograniczenie tej perspektywy.

Zdaniem Nicka Dyer-Witheforda kategoria pracy niematerialnej/ biopolitycznej, mimo że wolna od jednostronnego nacisku na twórczą

42 A. Callinicos, Antonio Negri and the Temptation of Ontology, [w:] The Philosophy of Antonio Negri 2: Revolution in Theory, red. T. S. Murphy, A.-K. Mustapha, London-Ann Arbor 2007; P. Green, 'The Passage from Imperialism to Empire': a Commentary on Empire by Michael Hardt and Antonio Negri, "Historical Materialism" 2002, Vol. 10, No. 1; A. Toscano, 'Always Already Only Now', [w:] The Philosophy of Antonio Negri 2...

43 A. Toscano, Always Already... 
pracę intelektualną, jest zbyt szeroka, by stać się podstawą konstrukcji klasowego podmiotu politycznego; proponuje on wyróżnienie trzech podkategorii, pozwalających na sprecyzowanie: pracy niematerialnej (pracy z informacja), pracy materialnej (usług i pracy opiekuńczej, rolnictwa) oraz pracy prekariatu (niestabilnej i pozbawionej ochrony pracy przemysłowej w sweatshopach byłego Trzeciego Świata) ${ }^{44}$. Nie chodzi przy tym o odrzucenie samej kategorii, ale o możliwość dokładniejszego określenia składu technicznego i politycznego. Przede wszystkim zyskujemy tu narzędzia umożliwiające ujęcie roli globalnych hierarchicznych podziałów pracy, dokonujących się wzdłuż linii państwowych, etnicznych i płciowych ${ }^{45}$.

Wysuwane przez Thoburna pod adresem Hardta i Negriego zarzuty absolutyzowania produkcji i niemożności dostrzeżenia wyzysku, choć wskazują na pewną tendencję obecną w podejściu Negriego do kwestii ewolucji kapitalizmu i pozycji pracy niematerialnej, nie uderzają jednak w samo jej centrum; należałoby je może nie całkowicie odrzucić, ale znacznie osłabić. Z kolei twierdzenie o większej przydatności pojęcia stawania-się-mniejszościowym dla teorii lewicowej budzi niejakie wątpliwości: Deleuze i Guattari nie mówią zbyt wiele o relacjach, łączących zarówno poszczególne przypadki stawania się, jak i powszechne stawanie-się-mniejszościowym z dynamiką kapitalizmu jako systemu opartego na spotkaniu strumienia zdekodowanej pracy i zdekodowanego kapitału i na nieograniczonej ekspansji aksjomatyki. W jaki sposób stawanie-się-mniejszościowym może się obronić przed aksjomatyzacją i włączeniem w obręb logiki kapitalizmu? Jedyną podstawą politycznej inwencji jest dla Deleuze'a i Guattariego deterytorializacja, będąca jednakże dość abstrakcyjną kategorią ontologiczną. Można chyba uznać, że pojęcie pracy niematerialnej jako podstawy dynamiki zarówno kapitalizmu, jak i oporu wobec niego, może stanowić swego rodzaju konkretyzację idei politycznej deterytorializacji.

44 Są to raczej tendencje niż sektory wydzielone według kryteriów treściowych (rodzaj pracy) czy geograficznych: tendencja do prekaryzacji jest na przykład immanentna dla całego pola produkcji w postfordowskiej gospodarce, obejmując pracę materialną i częściowo niematerialną: niemal każdy zawód może stać się junk job (zob. N. Dyer-Witheford, Cyber-Negri..., s. 156).

45 Tamże, s. 152. 
Filozofia Deleuze'a i Guattariego dostarcza teorii Negriego i Hardta podbudowy ontologicznej; pozwala także, za sprawą pojęcia stawania-się-mniejszosciowym, bronić się przed taką jej interpretacją, która przyznałaby podmiotowi pracy produkcyjnej (niematerialnej/biopolitycznej) status bezpośredniego podmiotu emancypacji, niewymagającej uwolnienia się od wyzysku i artykulacji politycznej. Teoria autorów Multitude z kolei pozwala zarysować powiązanie między pragnieniem-produkcją jako kategorią ontologiczną a produkcją jako bliższą empirii kategorią ekonomiczno-społeczną. 
Joanna Bednarek: ur. 1982, filozofka z zawodu i powołania, pisarka z powołania. Pracę doktorską Polityka poza formą: ontologiczne uwarunkowania poststrukturalistycznej filozofii polityki obroniła w 2011 roku. Publikowała w „Nowej Krytyce”, „Czasie Kultury” i „Krytyce Politycznej”. Współpracuje z Pracownią Pytań Granicznych i z Interdyscyplinarnym Centrum Badań Płci Kulturowej i Tożsamości UAM. W latach 2006-2009 współpracowała z „Krytyką Polityczną”. Obszar kompetencji i zainteresowań: na przecięciu poststrukturalizmu, feminizmu, marksizmu autonomistycznego i literatury.

Dane kontaktowe:

Joanna Bednarek

Międzywydziałowa Pracownia Pytań Granicznych UAM

Collegium Maius

ul. Fredry 10

60-701 Poznań

e-mail: bednarekjoanna87@gmail.com

Cytowanie:

J. Bednarek, Praca biopolityczna i nowy sktad klasowy. (Pragnienie-produkcja i żywa praca 2 - Hardt i Negri), „Praktyka Teoretyczna” nr 5/2012, http://www.praktykateoretyczna.pl/PT_nr5_2012_Logika_sensu/16. Bednarek.pdf (dostęp dzień miesiąc rok)

Author: Joanna Bednarek

Title: Biopolitical labor and the new class composition (Desiring-production and living labor 2 - Hardt and Negri)

Summary: The article is committed to the aim of reconstruction of the notion of immaterial/biopolitical labor in the context of its affinities with Deleuze and Guattari's notion of desiring-production. Hardt and Negri's controversial thesis of the autonomization of biopolitical labor from capitalist command as the basis for the political emancipation of the working class/multitude is also discussed and compared with Deleuze and Guattari's vision of becoming-minoritarian as the only viable anti-capitalist politics.

Key words: biopolitics, production, operaismo, immaterial labor, Negri, Hardt 